\title{
Domestic Demand-driven Growth: Analytical Perspectives and Statistics Needed
}

\author{
Yeah, Kim Leng \\ Sunway University, Business School, Malaysia
}

Copyright $(2017$ by authors, all rights reserved. Authors agree that this article remains permanently open access under the terms of the Creative Commons Attribution License 4.0 International License

\begin{abstract}
Given the imbalances in global demand and sluggish growth in the advanced economies, which had absorbed the bulk of world exports before the onset of the 2008/09 global financial crisis (GFC), the shift from export-led growth (ELG) strategies to domestic demand-driven growth (DDDG) strategies appears inevitable for export-oriented economies. In dissecting Malaysia's growth performance into various demand components and sources, it was found that DDDG in Malaysia had helped to offset the weak export demand it had faced over the last decade and, importantly, during the post-GFC years. Using input-output tables to assess the changes in output structure arising from substituting current export demand with domestic demand, the analysis showed that the country's high export orientation in a large number of industries precludes its ability to fully offset any sharp decline in exports. The implication is that DDDG can only effect a partial decoupling from external demand and that given the differences in the composition of export and domestic demand, there will be sectoral differences in the impact on industrial capacity, employment and income arising from the ELG-DDDG shift. In cross-country comparisons, Malaysia's 'apparent' under-consumption and low private investment levels, in concert with its narrowing but still positive savings-investment gap, lend further support to the feasibility and desirability of promoting DDDG to support economic growth. Importantly, DDDG is sustainable only if it maximizes economic efficiency and utilization of resources, skills, human capital, and physical and social infrastructures subject to structural, credit and other constraints. On the consumption side of DDDG, a higher level of spending by the middle and upper income groups will need to be elicited while the income of the low income groups will need to be boosted. Private investment, regardless of domestic or foreign sources or DDDG versus ELG orientation, will be one of the key drivers of DDDG, given the excess savings in the private sector as well as the capacity expansion and productivity growth associated with gross fixed capital formation. Some evidence of lower productivity growth in domestic-oriented industries
\end{abstract}

compared to export-oriented ones reiterates the need for policy measures to boost productivity as part of the DDDG thrusts. Based on a suggested DDDG framework, whereby the fundamental sources of economic growth emanate from output and structural shifts to higher value activities, productivity increases and institutional quality improvements, the statistical needs are examined for each of the four suggested strategic DDDG thrusts. The paper reiterates that DDDG should not be viewed as a substitute for export-led growth (ELG) strategies. Rather, by harnessing the complementarities of the two paradigms, Malaysia can capture the growth opportunities arising from an upswing in external demand while mitigating the adverse effects on output and employment due to volatile export markets by strengthening the resilience of domestic demand.

Keywords Domestic Demand-driven Growth, Export-led Growth Strategy, Growth Sustainability, Productivity Shifts, Production Structure, Statistical Needs

\section{Introduction}

In the aftermath of the 2008/09 global financial crisis (GFC), the growth in world exports of goods and services has halved to $4.0 \%$ from an average increase of $8.2 \%$ per annum in the pre-crisis $2003-07$ period and $7.3 \%$ in the $1990 \mathrm{~s}$. Consequently, countries focusing on export-led growth strategies will unlikely be able to achieve their desired pre-GFC growth rates. With the G3 economies (US, Japan and Europe) remaining fragile and unable to resume trend or potential output growth in the foreseeable future, their import levels will likely remain below the pre-GFC levels for a prolonged and possibly decade-long period.

Malaysia's export-oriented growth strategy is once again under scrutiny given the changes in the post-global crisis economic landscape. A notable feature is that developing economies as well as export-oriented industrialized economies are confronted with the urgent need to deal with 
weak or slumping growth in the G3 economies (US, Japan and Europe) while acceding to calls to increase domestic absorption and redress the imbalance in global demand.

This paper will present various analytical perspectives on the feasibility and challenges of implementing DDDG for the Malaysia economy. The analyses also serve to highlight the statistics needed to extend the research and to inform policy debates. The basis for DDDG is first examined in section 2 where the advantages and disadvantages of DDDG versus export-led growth (ELG) strategies are elucidated. In section 3 , various economic analyses are presented to determine the efficacy and necessary conditions for DDDG to succeed as well as to illustrate the various types of official statistics employed. In the section 4, a framework for formulating DDDG strategies is suggested together with the statistics required. Section 5 concludes with some broad findings and observations on the feasibility of DDDG for Malaysia and related statistical needs for more in-depth analyses.

\section{Basis for Domestic Demand-driven Growth (DDDG)}

Malaysia, and most East Asian economies, have benefitted from trade openness and the pursuit of export-led growth (ELG) strategy since the early 1970s. China's entry into the World Trade Organization in 2001 and its phenomena growth and emergence as the world's largest manufacturer in 2011 has lent further credence to the efficacy of export-led growth (ELG) strategies. In the aftermath of the 2008/2009 global financial crisis, the prolonged weakness in the advanced economies however has led to a renewed focus on domestic demand-driven growth strategies especially among the export-oriented Asian economies [1].

Compared to ELG strategies, DDDG offers the following advantages:

- $\quad$ Reduced vulnerability to global demand shocks: Given the increasing volatility and unpredictability of international markets and doubts over the ability of advanced economies to absorb all exports from developing countries, a DDDG strategy will lead to more stable and sustainable growth.

- Prospects for better quality of growth: The pursuit of export growth to the extreme of mercantilism whereby trade is viewed as a zero-sum game may entail sacrificing labor and human rights and environmental standards, leading to a worse outcome than a DDDG approach that takes into consideration such concerns.

- Development of a more balanced economy and fuller utilization of resources: The production of goods and services that caters to foreign demand tends to be highly concentrated, leading to unbalanced growth and more pronounced income inequality. A DDDG strategy on the other hand can lead to a more optimal utilization of resources.
The disadvantages of DDDG, which mirror in reverse the benefits of ELG, include:

- Small market constraints: For small economies, the limited domestic markets inhibit industries from reaping efficiency gains from economies of scale in production and sales.

- Demonstration effects and knowledge spillovers: Being confined to domestic markets, there is less pressure as well as fewer opportunities to learn from more sophisticated demand in the more advanced markets.

- Protectionist tendencies: Domestic industries, when threatened with import competition, tend to seek government assistance, leading invariably to protectionism.

- Baumol's cost and growth diseases: Since export industries tend to be more efficient and internationally competitive, a shift to domestic-oriented sectors with lower efficiency and productivity could result in stagnating or lower growth.

ELG critics have argued that trade openness and ELG strategy has been oversimplified and oversold [2]. In examining the relative merits and pitfalls of DDDG versus ELG, policy makers and planners should not view it as an 'either-or' menu choice but rather to optimize their complementarities in order to maximize the country's growth potential as well as to strengthen national competitiveness.

Such policy analyses will require various macro, industry and firm-level data that can illuminate the relative importance and role of domestic demand in Malaysia's changing patterns of growth and its demand and production as discussed next.

\section{Analysis of Domestic Demand-driven Growth}

The strategic fit of DDDG to Malaysia's economic development can be elucidated through an analysis of the role and contribution of domestic demand to the country's growth, structural change and competitiveness in relation to the domestic and external sector balances, as well as the changing dynamics of international trade and investment flows.

In the sections below, several analyses performed to shed further light on the efficacy of DDDG as well as to highlight the use of official statistics and data gaps.

\subsection{Contribution of Aggregate Domestic Demand to Economic Growth}

\subsubsection{Growth Rate and Contribution Analysis of Domestic Final Demand}

Over the decades, the pace of aggregate domestic final demand expansion in the Malaysian economy moderated to $5.8 \%$ in the $2000 \mathrm{~s}$ from $6.4 \%$ in the 1990 s. There was a sharp 
deceleration in net export growth from $39.0 \%$ to $0.1 \%$ as the country's GDP growth eased from $7.5 \%$ in the 1990 s to $4.9 \%$ per annum in the 2000s. Over the two decades, the contribution of aggregate domestic final demand to GDP growth showed a slight decrease from 5.5 percentage points (ppts) to 4.9 ppts while net exports' contribution registered a sharper decline from 2.0 ppts to $0.1 \mathrm{ppt}$ (Table 1 and Figure 2).

The shift to DDDG was more pronounced in the post-global crisis period from 2010-12 whereby aggregate domestic final demand contributed 7.4 ppts while net exports' contribution was negative at 2.2 ppts. GDP growth averaged
$6.1 \%$ per annum in both the pre and post-global financial crisis (GFC) periods (Table 1).

The above trends suggest that contribution of net exports to GDP growth had begun to decline during the last decade (2001-2010). The decline was magnified by slumping exports in the post-GFC period. Conversely, domestic demand was already the main driver of growth before the global financial crisis and its importance was accentuated by the onset of the GFC. Nevertheless, exports of goods and services, despite expanding at half the pace in the 1990s, still constitute a sizeable share of the economy as examined in the next section.
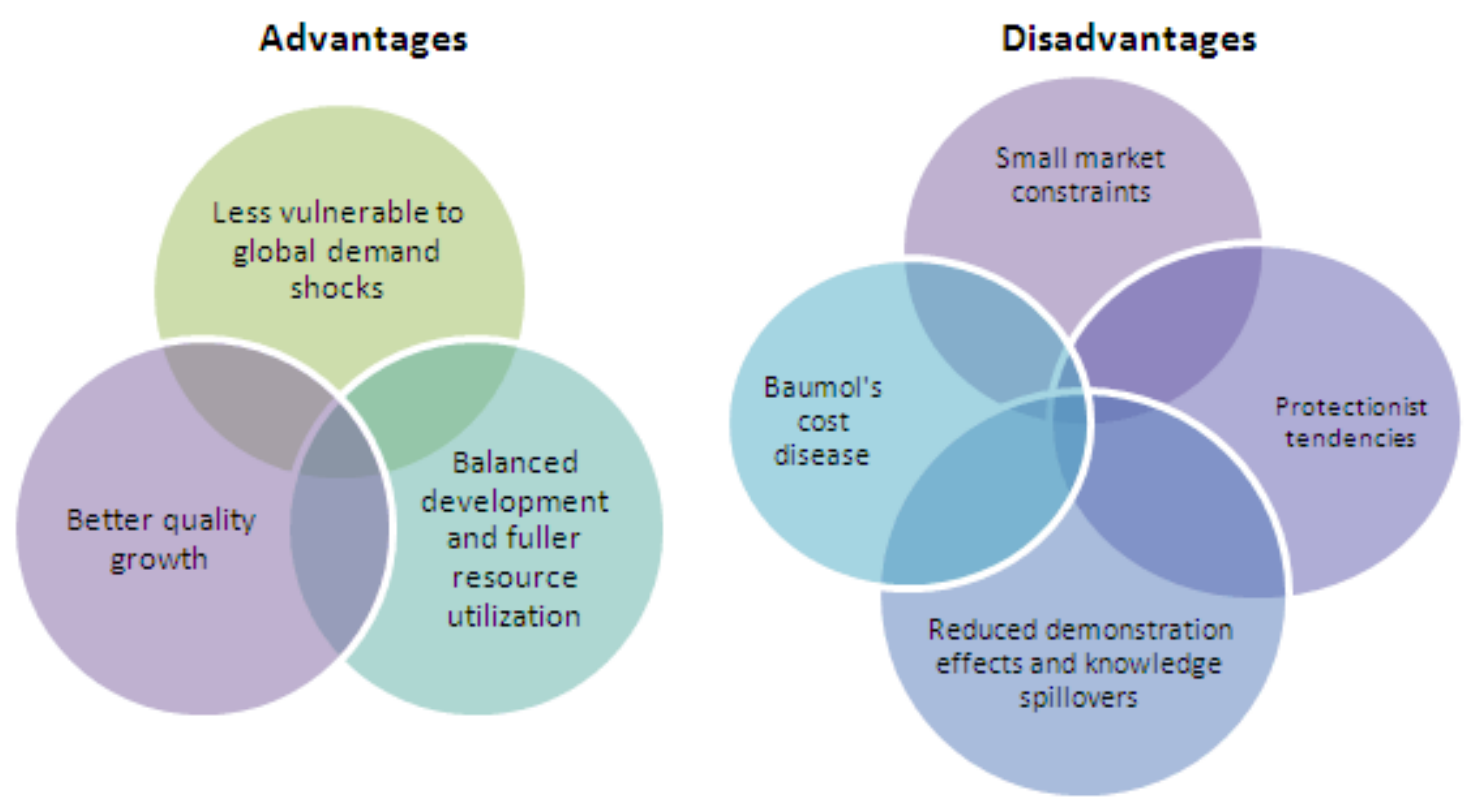

Figure 1. DDDG's advantages and disadvantages

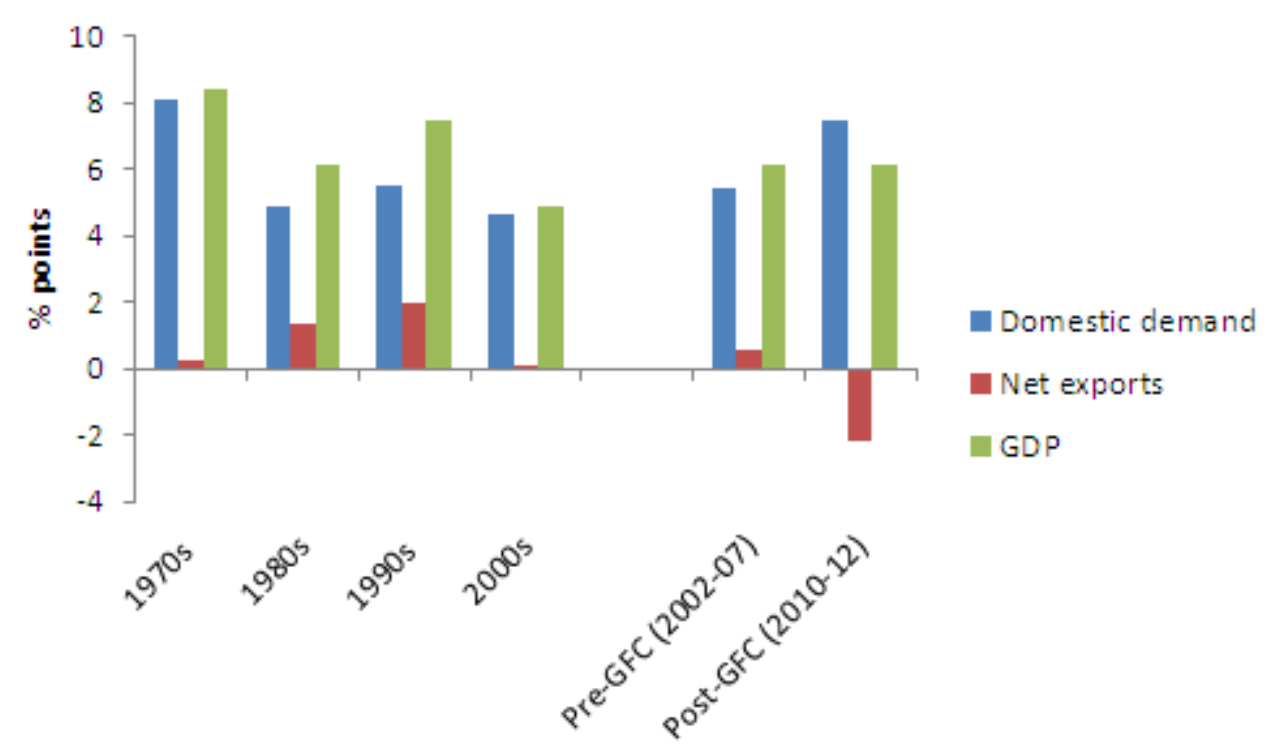

Source: Computed from national account statistics published by Department of Statistics Malaysia; based on constant 2005 prices.

Figure 2. Contribution of domestic demand and net exports to GDP growth 
Table 1. Contribution of domestic demand and net exports to Malaysia's GDP growth performance

\begin{tabular}{|c|c|c|c|}
\hline & $\begin{array}{l}\text { Domestic final } \\
\text { demand }\end{array}$ & Net exports & $\begin{array}{c}\text { Gross Domestic Product } \\
\text { (GDP) }\end{array}$ \\
\hline \multicolumn{4}{|l|}{ Average annual growth (\%) } \\
\hline 1970s $(1971-80)$ & 9.1 & 13.7 & 8.4 \\
\hline 1980s (1981-90) & 5.6 & -57.7 & 6.2 \\
\hline 1990s (1991-2000) & 6.4 & 39.0 & 7.5 \\
\hline 2000s (2001-10) & 5.8 & 0.1 & 4.9 \\
\hline Pre-GFC (2002-07) & 7.0 & 2.4 & 6.1 \\
\hline Post-GFC (2010-12) & 7.6 & -7.9 & 6.1 \\
\hline \multicolumn{4}{|l|}{ Share to GDP (\%) } \\
\hline 1970 & 93.1 & 7.2 & 100.0 \\
\hline 1980 & 97.2 & 2.4 & 100.0 \\
\hline 1990 & 89.7 & 10.2 & 100.0 \\
\hline 2000 & 76.4 & 23.8 & 100.0 \\
\hline 2010 & 84.0 & 14.8 & 100.0 \\
\hline 2012 & 86.5 & 13.1 & 100.0 \\
\hline \multicolumn{4}{|c|}{ Contribution to GDP growth (\% points) } \\
\hline 1970s $(1971-80)$ & 8.1 & 0.3 & 8.4 \\
\hline 1980s (1981-90) & 4.9 & 1.3 & 6.2 \\
\hline 1990s (1991-2000) & 5.5 & 2.0 & 7.5 \\
\hline 2000s (2001-10) & 4.6 & 0.1 & 4.9 \\
\hline Pre-GFC (2002-07) & 5.4 & 0.6 & 6.1 \\
\hline Post-GFC (2010-12) & 7.4 & -2.2 & 6.1 \\
\hline
\end{tabular}

Source: Computed from national accounts statistics published by Department of Statistics Malaysia; all series rebased to 2005 constant prices. Totals may not tally due to stock changes which are excluded from domestic final demand.

Table 2. Malaysia's changing demand structure and growth performance ${ }^{1}$

\begin{tabular}{|c|c|c|c|c|c|c|c|c|c|c|}
\hline & \multicolumn{3}{|c|}{ Consumption } & \multicolumn{3}{|c|}{ Gross fixed capital formation } & \multirow{2}{*}{ Stocks } & \multirow{2}{*}{$\begin{array}{c}\text { Exports } \\
\text { of goods } \\
\& \\
\text { services }\end{array}$} & \multirow{2}{*}{$\begin{array}{c}\text { Imports } \\
\text { of goods } \\
\& \\
\text { services } \\
\end{array}$} & \multirow{2}{*}{$\begin{array}{l}\text { GDP at } \\
\text { market } \\
\text { prices }\end{array}$} \\
\hline & Total & Private & Public & Total & Private & Public & & & & \\
\hline \multicolumn{11}{|l|}{ Average annual growth (\%) } \\
\hline 1970s (1971-80) & 7.8 & 7.4 & 10.2 & 13.2 & 13.5 & 14.2 & 59.0 & 7.5 & 9.1 & 8.4 \\
\hline 1980s (1981-90) & 4.9 & 5.1 & 4.3 & 7.6 & 8.1 & 7.1 & -47.2 & 10.7 & 9.9 & 6.2 \\
\hline 1990s (1991-2000) & 5.7 & 5.8 & 5.5 & 8.2 & 7.6 & 10.8 & -330.4 & 12.5 & 12.3 & 7.5 \\
\hline 2000s (2001-10) & 6.9 & 6.7 & 7.7 & 3.6 & 4.6 & 4.6 & -103.8 & 4.1 & 5.0 & 4.9 \\
\hline 2010-12 (Post-GFC) & 7.4 & 6.8 & 9.5 & 8.5 & 13.9 & 2.3 & -127.1 & 7.8 & 10.9 & 6.1 \\
\hline \multicolumn{11}{|l|}{ Share to GDP (\%) } \\
\hline 1970 & 71.1 & 59.8 & 11.3 & 22.0 & 15.2 & 6.9 & -0.3 & 51.6 & 44.4 & 100.0 \\
\hline 1980 & 67.5 & 54.2 & 13.3 & 29.8 & 20.3 & 9.5 & 0.4 & 47.0 & 44.6 & 100.0 \\
\hline 1990 & 59.3 & 48.2 & 11.1 & 30.4 & 21.8 & 8.7 & 0.1 & 70.7 & 60.5 & 100.0 \\
\hline 2000 & 50.3 & 41.1 & 9.2 & 26.2 & 14.8 & 11.4 & -0.2 & 112.1 & 88.4 & 100.0 \\
\hline 2010 & 60.8 & 48.8 & 12.0 & 23.2 & 12.5 & 10.6 & 1.2 & 101.5 & 86.6 & 100.0 \\
\hline 2012 (Post-global crisis) & 63.0 & 49.8 & 13.2 & 23.5 & 13.4 & 10.1 & 0.5 & 100.6 & 87.5 & 100.0 \\
\hline \multicolumn{11}{|c|}{ Contribution to GDP growth (\% points) } \\
\hline 1970s $(1971-80)$ & 5.1 & 4.0 & 1.2 & 2.9 & 2.0 & 0.9 & 0.1 & 3.6 & 3.4 & 8.4 \\
\hline 1980s $(1981-90)$ & 3.0 & 2.4 & 0.6 & 1.9 & 1.3 & 0.6 & 0.0 & 6.0 & 4.7 & 6.2 \\
\hline 1990s (1991-2000) & 3.1 & 2.6 & 0.6 & 2.4 & 1.3 & 1.1 & 0.0 & 10.7 & 8.7 & 7.5 \\
\hline $2000 \mathrm{~s}(2001-10)$ & 3.8 & 2.9 & 0.8 & 0.8 & 0.4 & 0.5 & 0.2 & 4.2 & 4.1 & 4.9 \\
\hline 2010-12 (Post-GFC) & 4.5 & 3.3 & 1.1 & 1.9 & 1.7 & 0.3 & 1.0 & 7.7 & 8.9 & 6.1 \\
\hline
\end{tabular}

Source: Derived from national accounts statistics published by Department of Statistics Malaysia; all series rebased to 2005 constant prices. 


\subsubsection{Breakdown by Demand Components}

A disaggregation of the performance of the various demand components, as shown in Table 2, will shed further light on their relative role and contribution to GDP growth.

Malaysia's export-led growth was most evident in the 1970s till the 1990s. Export growth averaged 7.5\% in the $1970 \mathrm{~s}$, rising to $10.7 \%$ in the $1980 \mathrm{~s}$ and $12.5 \%$ in the $1990 \mathrm{~s}$. The corresponding GDP growth rates were $8.4 \%, 6.2 \%$ and $7.5 \%$ per annum (Table 2 ). There was a marked slowdown in Malaysia's external trade in the 2000s. Average annual export growth more than halved to $4.1 \%$ while import growth averaged slightly higher at $5.0 \%$ per annum. In the post-GFC period (2010-12), exports picked up pace to $7.8 \%$ while imports grew at $10.9 \%$ per annum.

Meanwhile, the share of exports to GDP peaked at $112 \%$ in 2000 before declining to a low of $103 \%$ in 2003. It then rose to a high of $114 \%$ in 2006 before easing to $97.6 \%$ in 2009 during the height of the global financial crisis. Since then, it has picked up slightly to $100.5 \%$ of GDP in 2012 , suggesting that the share of exports in the economy remains sizeable despite its slower growth during the last decade as well as during the post-GFC period.

Private consumption and investment, which averaged around $70 \%$ of GDP in the earlier decades prior to the 1997/98 Asian Financial Crisis (AFC), fell to an average of $58 \%$ between then and 2012. It exhibits a rising trend since the AFC and, in contrast to previous recessions where it took a dip, did not experience any decline during the most recent recession caused by the GFC.

The resilience of private sector demand during the GFC can be attributed to a number of factors such as aggressive monetary easing and government stimulus programmes, pent-up demand and high savings, stable commodity prices, continuing credit flows, among others. The pent-up demand explanation is explored further in section 3.2.1 where the country's under-consumption and under-investment is examined further.

Given the significant share of exports in the economy, the feasibility of DDDG to sustain growth will have to take into consideration the production structure and its substitutability with domestic demand as analyzed in section 3.2.

\subsubsection{Decomposition of Sources of Demand}

A commonly used approach to estimate the various sources of demand is the structural decomposition analysis (SDA). The technique decomposes aggregate demand into domestic demand expansion, import substitution and export demand expansion. Using the input-output (IO) tables of Malaysia for 1991, 2000 and 2005 published by the Department of Statistics Malaysia, the country's sources of demand is decomposed for two periods, 1991-2000 and 2000-2005 and the results are summarized in Table 3. 
Table 3. Decomposition of sources of demand for 1991-2000 and 2000-05 (percent)

\begin{tabular}{|c|c|c|c|c|c|c|c|c|}
\hline \multirow[b]{2}{*}{ Sector } & \multicolumn{4}{|c|}{$1991-2000$} & \multicolumn{4}{|c|}{$2000-2005$} \\
\hline & $\begin{array}{c}\text { Domestic } \\
\text { demand }\end{array}$ & $\begin{array}{l}\text { Import } \\
\text { demand }\end{array}$ & $\begin{array}{c}\text { Export } \\
\text { demand }\end{array}$ & Total & $\begin{array}{c}\text { Domestic } \\
\text { demand }\end{array}$ & $\begin{array}{l}\text { Import } \\
\text { demand }\end{array}$ & $\begin{array}{c}\text { Export } \\
\text { demand }\end{array}$ & Total \\
\hline AGRICULTURE & 172 & (17) & (55) & 100 & 158 & 4 & $(62)$ & 100 \\
\hline Other agriculture & 79 & (48) & 69 & 100 & 11 & (13) & 102 & 100 \\
\hline Fisheries & 98 & 1 & 1 & 100 & 116 & (49) & 33 & 100 \\
\hline Forestry & 339 & (15) & (224) & 100 & 98 & (3) & 6 & 100 \\
\hline MINING & 122 & (13) & (9) & 100 & 129 & 42 & (71) & 100 \\
\hline MANUFACTURING & 89 & (22) & 33 & 100 & 115 & 40 & $(55)$ & 100 \\
\hline Consumer Goods & 91 & (4) & 13 & 100 & 91 & 11 & (2) & 100 \\
\hline Food, bev. \& tobacco & 101 & 3 & (4) & 100 & 85 & (1) & 15 & 100 \\
\hline Wearing apparel \& footwear & 119 & 22 & (41) & 100 & 160 & (8) & $(52)$ & 100 \\
\hline Paper \& furniture & 59 & (83) & 124 & 100 & 112 & 60 & $(72)$ & 100 \\
\hline Prof. \& scientific equip. & 74 & 6 & 20 & 100 & 141 & 27 & $(68)$ & 100 \\
\hline Other manufactures & 44 & 35 & 22 & 100 & 84 & 26 & (10) & 100 \\
\hline Investment goods & 114 & (2) & (11) & 100 & 119 & 9 & $(28)$ & 100 \\
\hline Textiles & 122 & 18 & (41) & 100 & (69) & 128 & 41 & 100 \\
\hline Wood \& cork products & 272 & (15) & (157) & 100 & 277 & 7 & (184) & 100 \\
\hline Printing \& publishing & 84 & 8 & 8 & 100 & 73 & 15 & 12 & 100 \\
\hline Industrial chemicals & 80 & 19 & 1 & 100 & 146 & 21 & (67) & 100 \\
\hline Other chemicals & 46 & 3 & 52 & 100 & 100 & (4) & 3 & 100 \\
\hline Petroleum refineries & 114 & (17) & 3 & 100 & 102 & 5 & (7) & 100 \\
\hline Rubber products & 171 & $(48)$ & (22) & 100 & 256 & 59 & (215) & 100 \\
\hline Plastic products & 68 & (13) & 45 & 100 & 165 & 42 & $(108)$ & 100 \\
\hline Cement, clay \& other NMMP & 89 & (12) & 23 & 100 & 99 & (5) & 6 & 100 \\
\hline Glass \& glass products & 113 & 4 & (17) & 100 & 126 & 11 & (37) & 100 \\
\hline Capital goods & 79 & (27) & 48 & 100 & 123 & 66 & (89) & 100 \\
\hline Iron \& steel basic industries & 107 & (39) & 33 & 100 & 44 & 30 & 26 & 100 \\
\hline Non-ferrous metals & 93 & (17) & 24 & 100 & 182 & 151 & (234) & 100 \\
\hline Fabricated metal products & 130 & (21) & (9) & 100 & 87 & 4 & 9 & 100 \\
\hline Non-electrical machinery & 54 & (11) & 57 & 100 & 155 & 2 & $(57)$ & 100 \\
\hline Electrical machinery & 88 & $(17)$ & 29 & 100 & 137 & 97 & (133) & 100 \\
\hline Transport equipment & 112 & (78) & 66 & 100 & 81 & 4 & 15 & 100 \\
\hline CONSTRUCTION & 71 & 6 & 23 & 100 & 124 & (3) & (21) & 100 \\
\hline SERVICES & 102 & (13) & 11 & 100 & 83 & 14 & 2 & 100 \\
\hline Utilities & 96 & 2 & 2 & 100 & 89 & 0 & 11 & 100 \\
\hline W\&R trade, hotels \& rest. & 116 & (15) & (1) & 100 & 68 & 29 & 3 & 100 \\
\hline Transp. storage \& comm. & 106 & (16) & 10 & 100 & 107 & 32 & $(40)$ & 100 \\
\hline Fin., insur. \& real estate & 97 & (3) & 6 & 100 & 72 & 7 & 22 & 100 \\
\hline Business services & 71 & (31) & 60 & 100 & 102 & 7 & (9) & 100 \\
\hline TOTAL ECONOMY & 93 & (22) & 29 & 100 & 103 & 26 & (29) & 100 \\
\hline
\end{tabular}

Source: Computed from Input-output Tables of Malaysia for 1991, 2005 and 2005 published by Department of Statistics Malaysia. 
The decomposition results re-affirmed the rising role of domestic demand in explaining Malaysia's growth performance in the post-AFC period, as represented by the 2000-2005 period, compared to the 1990s as established earlier in the growth rate and contribution analysis.

In the 1991-2000 period, export demand expansion accounted for $29 \%$ of total demand whilst in the following period 2000-2005, there was decline of the same magnitude. Both domestic demand and import demand expansion contributed the bulk of the demand during the first half of the 2000s decade.

\subsubsection{Relationship with GDP Growth}

As expected, the growth in the various domestic demand aggregates is strongly correlated with GDP growth with a correlation coefficient of 0.97 for domestic final demand, 0.81 for imports, 0.82 for private investment and 0.80 for private consumption. The correlation coefficient for export growth is lower at 0.61 (Figure 4).

Correlation however does not imply causation. Since establishing causality is outside the scope of this paper, we can draw upon the findings of several studies using econometric tests such as Granger causality and co-integration techniques. Mixed or inconclusive results were obtained in a number of empirical studies on export-led growth. A study by Lai [3] that included the role of domestic demand found that both ELG and DDDG hypothesis are valid in the short run but the results are not supportive of ELG hypothesis in the long run. Instead the study found highly significant positive impact of domestic expenditure on economic growth.

\subsubsection{Output Gap and Demand}

The gap between actual and potential growth provides an indication of the extent to which demand, both domestic and external, can be stimulated without resulting in excessive inflationary pressures. The economy's potential growth can be estimated from a 'production function' approach where the fundamental sources of growth are derived from the production factors, capital and labour, and total factor productivity (TFP).

The decomposition results are shown by decades in Table 4. The forecasts for the 2013-20 periods are based on labour input growth of $2 \%$ per annum and capital input growth of $8 \%$ per annum. Assuming that TFP growth can be maintained at $1.5 \%$ per annum, broadly similar to the previous decade's achievement, Malaysia's potential growth is projected at $5.2 \%$ per annum for the rest of this decade.

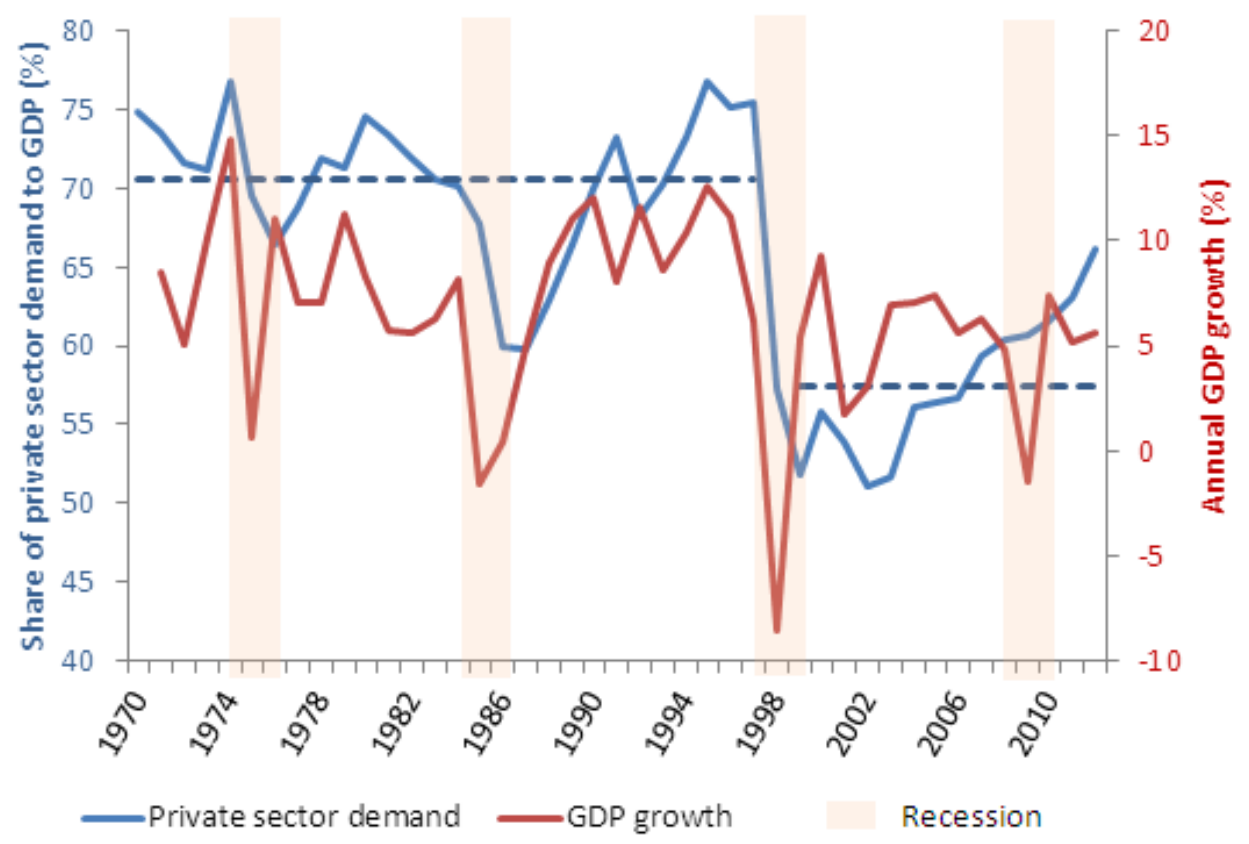

Figure 3. Private sector demand and GDP growth trends 


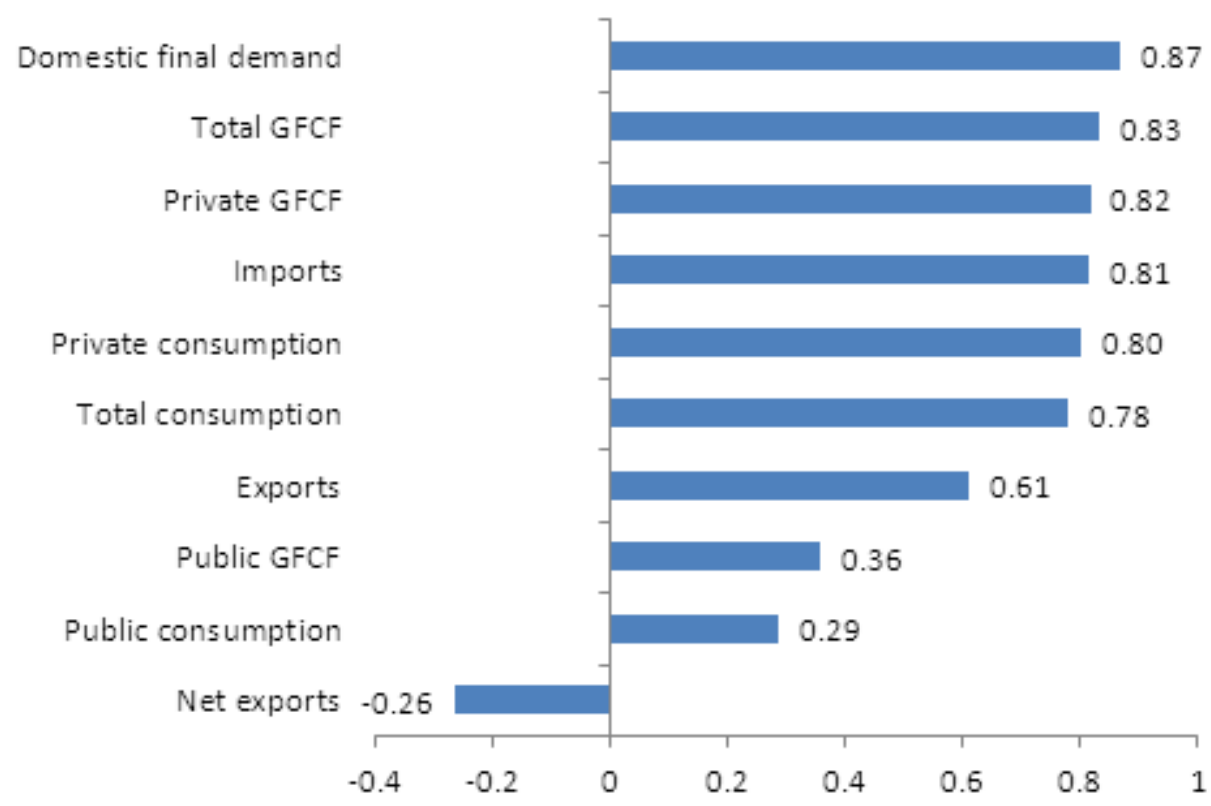

Sources: Computed from national account statistics published by Department of Statistics Malaysia with 2005 as the base year.

Figure 4. Correlation of growth of demand components with GDP growth for 1971-2012

Table 4. Growth decomposition and estimated potential output based on the production function approach

\begin{tabular}{|c|c|c|c|c|c|c|c|c|}
\hline \multirow{2}{*}{ Period } & \multicolumn{4}{|c|}{ \% point contribution to GDP growth } & \multicolumn{4}{c|}{ \% share of total contribution } \\
\cline { 2 - 10 } & Capital & Labour & TFP & TOTAL & Capital & Labour & TFP & TOTAL \\
\hline $1971-80$ & 3.6 & 2.6 & 1.1 & 7.3 & $50 \%$ & $34 \%$ & $16 \%$ & $100.0 \%$ \\
\hline $1981-90$ & 3.1 & 2.3 & 0.6 & 6.0 & $51 \%$ & $38 \%$ & $11 \%$ & $100.0 \%$ \\
\hline $1991-00$ & 2.6 & 2.5 & 2.1 & 7.2 & $36 \%$ & $35 \%$ & $29 \%$ & $100.0 \%$ \\
\hline $2001-12$ & 1.5 & 1.8 & 1.6 & 4.8 & $30 \%$ & $37 \%$ & $33 \%$ & $100.0 \%$ \\
\hline $2013-20 f$ & 2.3 & 1.4 & 1.5 & 5.2 & $44 \%$ & $27 \%$ & $29 \%$ & $100.0 \%$ \\
\hline
\end{tabular}

Source: Computed using Gollop-Jorgenson translog production function; 2013-20 forecasts based on labor input growth assumption of 2\% per annum and capital input growth of $10 \%$ per annum.

The policy implication arising from the above analysis is that a DDDG thrust that sustains growth at around the estimated potential output of $5.2 \%$ per annum will not result in a negative output gap (actual exceeding potential output) that signals the build-up of inflationary pressures. Another implication is that if an investment-targeted DDDG thrust is able to raise the annual investment rate to $10 \%$, then the country's potential output is lifted to $5.7 \%$, assuming no change in the other variables.

\subsection{Sustainability of Domestic Demand-driven Growth}

While the empirical issue of causality between domestic demand and growth may seem trivial, the main concern with the DDDG strategy is its sustainability and ability to duplicate the benefits associated with an ELG strategy while avoiding the costs highlighted in section 2 . To shed light on the sustainability issue, we examine the structure of demand components for any imbalances that may constrain growth in the short and long run. The findings presented next augur well for sustaining a DDDG-oriented strategy while simultaneously capturing the complementarities of ELG more fully.

\subsubsection{Under-consumption and Under-investment}

As shown in Figure 5, the share of private consumption to GDP turned around in 2000 after falling to its lowest level of $40 \%$ in 1999 . Since then, private consumption growth has risen $6.7 \%$ annually in the $2001-2010$ period from an average of $5.8 \%$ in the $1990 \mathrm{~s}$ and $5.1 \%$ in the $1980 \mathrm{~s}$. Meanwhile, its share to GDP has risen steadily to about $50 \%$ of GDP in 2012, thereby contributing to the robustness of domestic demand and helping to offset the weaker export demand.

Despite the rise over the last decade, there is an 'apparent under-consumption' when compared to the various country groupings by income levels as shown in Figure 6. Over the last decade, Malaysia's household final expenditure to GDP averaged $46 \%$ or about 10 percentage points below that of upper middle income countries (average 56\% GDP share) and 16 percentage points below that for high income countries (average 62\% GDP share).

More recently in 2010, the difference with the upper middle income and high income groups has closed to 5 and 15 percentage points respectively, suggesting that there is 
significant scope to boost private consumption (or its equivalent, household final expenditure) as part of DDDG strategy.

Malaysia's private investment similarly exhibits an even more pronounced 'under-investment' phenomenon, an issue that has attracted much research interest. Private investment growth slowed to $4.6 \%$ per annum in the 2000 s decade compared to $7.6 \%$ in the 1990 s and $8.1 \%$ in the 1980 s (Table 2 ). Its share to GDP, which reached a peak of $34 \%$ in 1997 , slumped to a low of $9.1 \%$ in 2002 before fluctuating upwards to $13.4 \%$ in 2011 .

A cross-country comparison with the mean investment levels for different income groupings reveals not only the significant gap in Malaysia's private investment level but also the divergent trends, with the former rising and latter remaining flattish (Figure 7).

Since a significant portion of investments in Malaysia is undertaken by government-linked firms, it may be more appropriate to compare the total investment as shown in Figure 8. Malaysia's "under-investment" still holds when compared to the higher levels and rising trends exhibited in the low, middle and upper middle income countries. Malaysia's total investment was only slightly above the high income group in recent years despite the latter countries being already industrialized as well as struggling with low growth and high unemployment in the aftermath of the global financial crisis.
An investment-based DDDG strategy is certainly appropriate and sustainable given the under-investment, and importantly, the sizeable savings-investment gap (Figure 9). The excess national savings over investment in the private sector amounting to more than $16 \%$ of GDP in 2011 suggests that there is no aggregate domestic financing constraint to a private sector-led DDDG strategy.

On the other hand, given the negative savings-investment gap in the government sector, the role of government spending will have to be redefined for the DDDG strategy to be sustainable. The fallacy of composition also applies in this case as what is true for the whole may not be true for the parts, notably the relatively high government debt level amounting to $54 \%$ of GDP in 2012 and household debt level at $80 \%$ of GDP in 2012.

\subsubsection{Rise in Private Sector Indebtedness}

A key factor underpinning the sustainability of domestic demand is leverage. It is noted that private sector credit-to-GDP, a widely used indicator of economy-wide leverage, peaked at 166\% of GDP in 1997 before the on-set of the Asian Financial Crisis (Figure 10). Following a decade-long deleveraging, the leverage ratio leveled off at $107 \%$ in 2008 before rising gradually to $128 \%$ of GDP in 2012 .

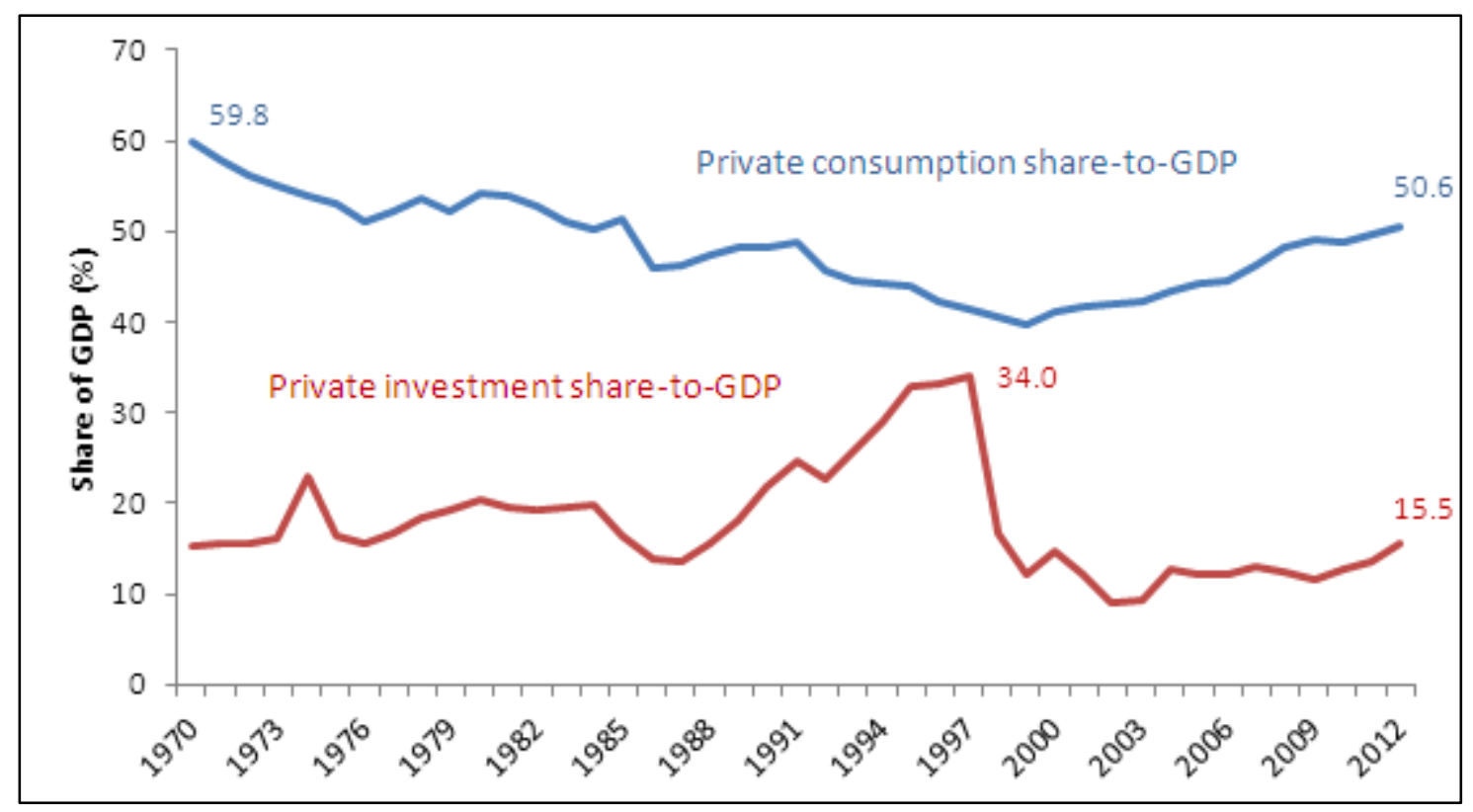

Source: Department of Statistics Malaysia; rebased to 2005 constant prices.

Figure 5. Trends in private consumption and private investment-to-GDP ratios 


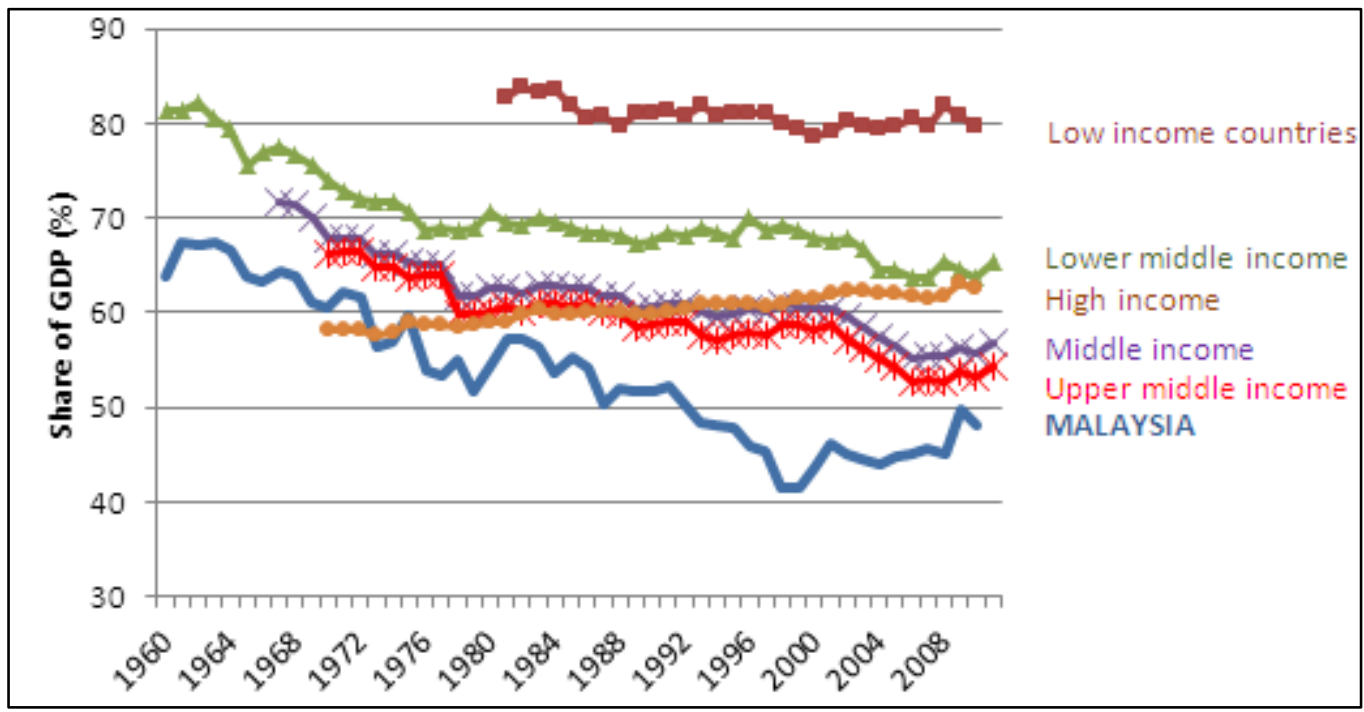

Source: The World Bank Databank

Figure 6. Comparison of household final expenditure among countries in different income groups

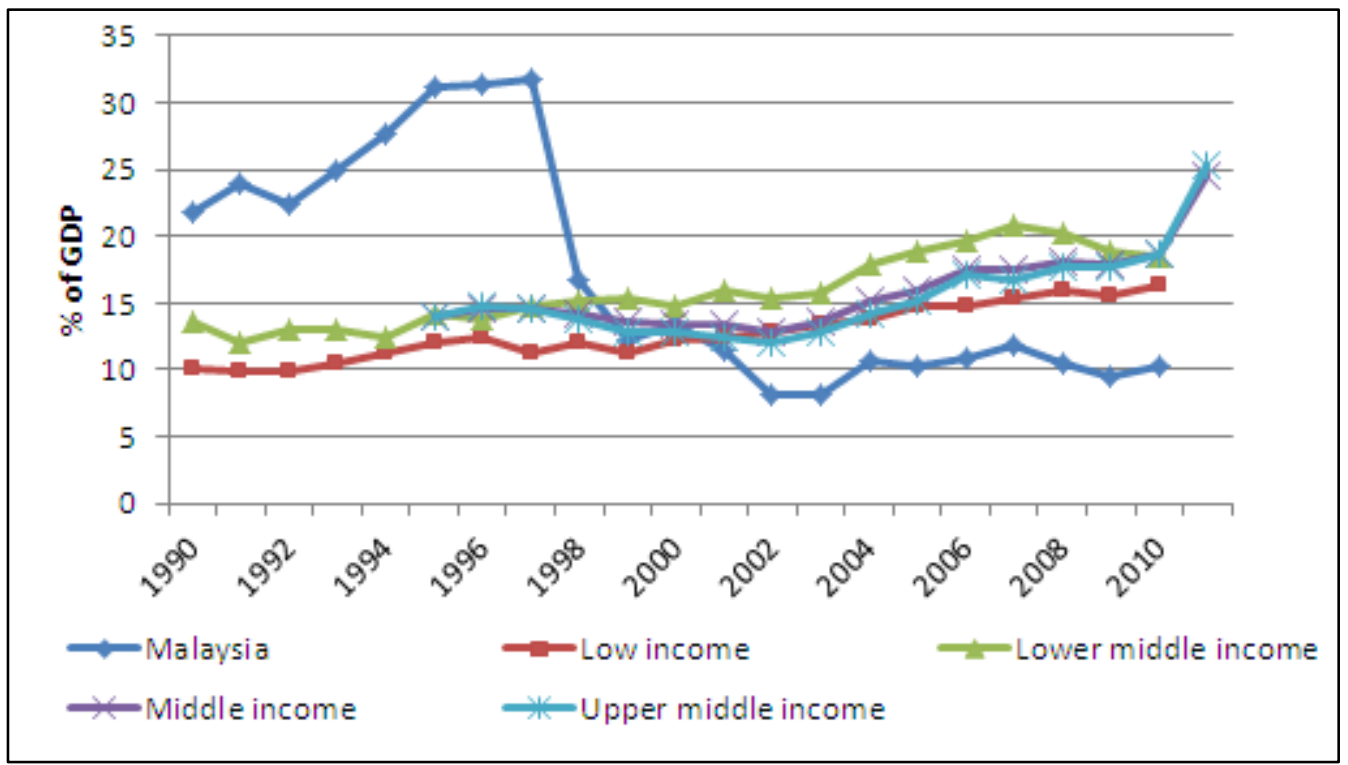

Source: The World Bank Databank

Figure 7. Trends in the GDP share of gross fixed capital formation by private sector for Malaysia and various country groupings 


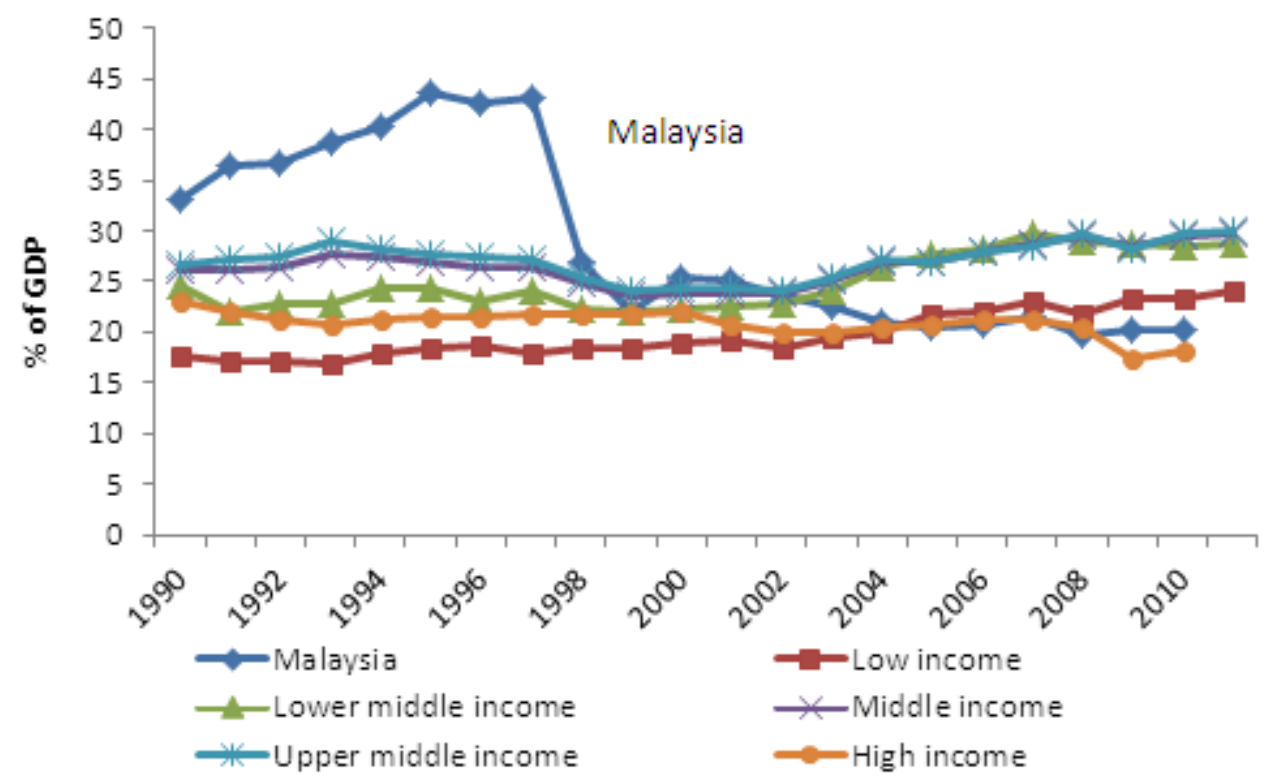

Source: The World Bank Databank

Figure 8. Comparison of total investment trends

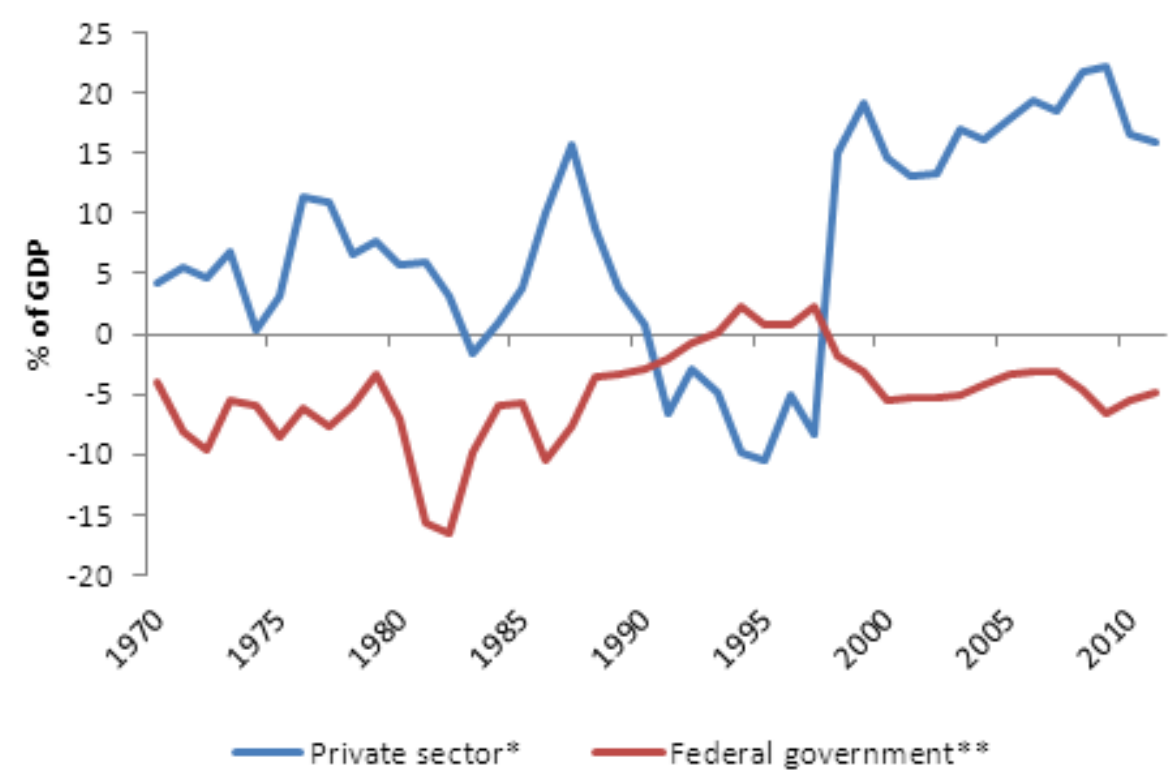

Note: *Based on current account balance - fiscal balance. **The federal government's fiscal deficit is used as the proxy for the savings-investment gap for the public sector.

Figure 9. Positive savings-investment gap for private sector but not the government 


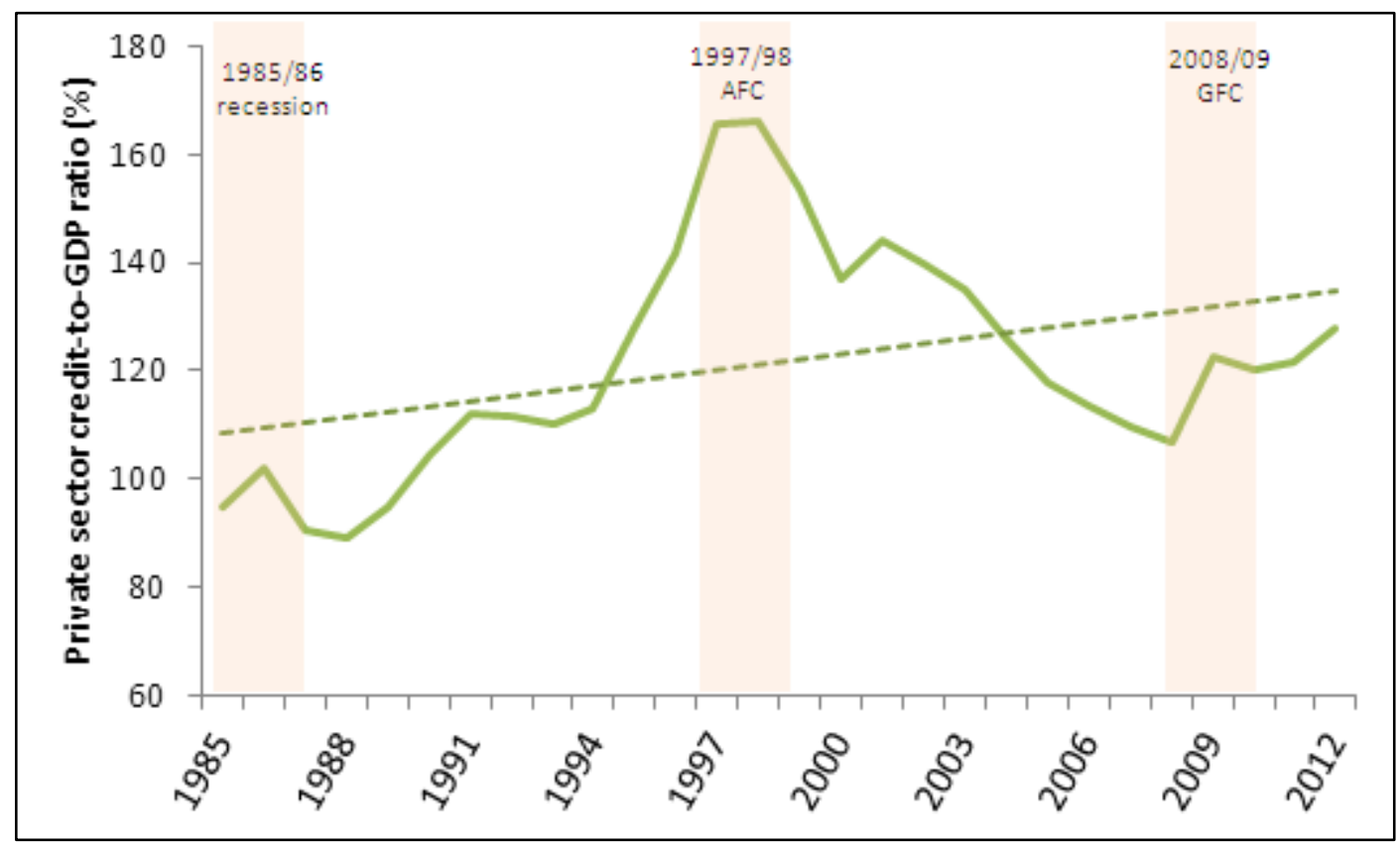

Source: Bank Negara Malaysia’s Monthly Statistical Bulletin.

Figure 10. Private sector leverage

Although the current leverage ratio is still lower than the pre-AFC level, it is nonetheless approaching the trend level. This suggests that any domestic demand-led expansion will be increasingly constrained by over-leveraging concerns as well as prudential measures taken by the central bank and lending institutions to guard against credit over-exposures.

\subsection{Changes in Production Structure and Productivity}

The changes in Malaysia's aggregate demand structure have been accompanied by marked shifts in its output structure. Its Malaysia's manufacturing sector slowed sharply in the 2000 s to $3.8 \%$ per annum in the 2000 s compared to $10.3 \%$ in the $1990 \mathrm{~s}$ and $9.8 \%$ in the $1980 \mathrm{~s}$. Correspondingly, its share to GDP declined to $25.2 \%$ in 2010 from $27.7 \%$ in 2000 after rising to $21.7 \%$ in 1990 from $14.7 \%$ in 1980 (Table 5).

An examination of the annual trend shows that manufacturing share to GDP peaked at $28.0 \%$ in 2006 before fluctuating downwards to $25.1 \%$ in $2011 .^{2}$ Services share to GDP meanwhile rose from $45.0 \%$ in 2000 to $53.2 \%$ in 2010 despite chalking slower growth of $6.4 \%$ per annum, down from $9.2 \%$ in the $1990 \mathrm{~s}$. The shares of resource-based sectors (agriculture and mining) continue to register decline but at a slower pace due to the rising but fluctuating commodity export demand.

These changes in production structure are consistent with the rising role of domestic demand as against export demand

2 Based on the 2000 constant price series, the manufacturing share to GDP is computed at $30.7 \%$ in 2005 . The rebasing to 2005 constant prices has resulted in a 'statistical drop' in the manufacturing GDP share when compared to those reported using different base year. This however does not change the finding of its declining share in the economy. since 2000. Besides the issue of sustainability, the rising importance of domestic demand and the pursuit of DDDG strategy give rise to two other concerns centered on demand rebalancing and inter-sectoral productivity shifts. Given the sizeable contribution of exports to the economy, amounting to approximately $101 \%$ of GDP in 2012, a DDDG strategy is desirable not only to offset export demand slack but also as a means to smooth output and ensure labor market stability.

The efficiency gains of re-allocating labor and capital resources to the more productive sectors will also need to be looked into given the well-known Baumol's diseases where price and cost increase not because of productivity growth but because of higher wages in other sectors. Applying this hypothesis to growth, changes in spending could result in slower economic growth because of the shift in composition of output away from industries with rapid productivity growth like manufacturing toward those with stagnant technologies like many types of services, resulting in overall slowdown in aggregate productivity growth. ${ }^{3}$ These issues will be addressed in the next section where the substitutability of domestic demand for export demand is analyzed.

\subsection{Substitutability of Domestic and Export Demand}

Given the availability of input-output tables for Malaysia, a partial equilibrium analysis is conducted to explore the implication of substituting export demand with domestic demand expansion. It is noted that more advanced

3 Norhaus [4] estimated that this 'disease' has lowered annual aggregate productivity growth in the US economy by slightly more than one-half percentage point over the last half century. 
approaches such as the use of computable general equilibrium (CGE) models are better suited to examine the economy-wide impact of substituting export demand with domestic demand. However, the development of CGE models is resource-intensive, given their complexity, software and specific data requirements, such as production transformation and substitution elasticities as well as income and expenditure flows in the form of social accounting matrix.

\subsubsection{Input-output Analysis of an Export Demand Shock}

A breakdown of Malaysia's production structure based on 34 industry groupings which have been aggregated from Malaysia's 120x120 input-output table for 2005 is shown in Table 6.

Table 5. Changes in Malaysia's production structure and sectoral performance

\begin{tabular}{|c|c|c|c|c|c|c|}
\hline & $\begin{array}{c}\text { Agriculture, } \\
\text { forestry \& } \\
\text { fishing }\end{array}$ & $\begin{array}{l}\text { Mining \& } \\
\text { quarrying }\end{array}$ & Manufacturing & Construction & Services & $\begin{array}{c}\text { GDP at } \\
\text { purchasers' } \\
\text { value }\end{array}$ \\
\hline \multicolumn{7}{|l|}{ Average annual growth (\%) } \\
\hline 1970s $(1971-80)$ & 6.1 & 7.5 & 14.7 & 9.9 & 9.9 & 8.4 \\
\hline 1980s (1981-90) & 3.4 & 3.7 & 9.8 & 3.5 & 6.2 & 6.2 \\
\hline 1990s (1991-2000) & 0.8 & 4.6 & 10.3 & 7.2 & 9.2 & 7.5 \\
\hline $2000 \mathrm{~s}(2001-10)$ & 2.9 & 0.4 & 3.8 & 3.0 & 6.4 & 4.9 \\
\hline Pre-GFC (2002-07) & 3.9 & 2.5 & 6.4 & 1.6 & 6.8 & 5.9 \\
\hline Post-GFC (2010-12) & 3.1 & -1.5 & 7.1 & 5.3 & 11.4 & 6.1 \\
\hline \multicolumn{7}{|l|}{ Share to GDP (\%) } \\
\hline 1970 & 26.8 & 28.8 & 9.2 & 4.6 & 32.8 & 100.0 \\
\hline 1980 & 20.4 & 23.6 & 14.7 & 4.9 & 35.4 & 100.0 \\
\hline 1990 & 16.7 & 19.4 & 21.7 & 3.9 & 38.0 & 100.0 \\
\hline 2000 & 8.9 & 14.8 & 27.7 & 3.6 & 45.0 & 100.0 \\
\hline 2010 & 7.6 & 9.8 & 25.2 & 3.0 & 53.2 & 100.0 \\
\hline 2012 (Post-GFC) & 7.3 & 8.4 & 24.9 & 3.5 & 54.6 & 100.0 \\
\hline \multicolumn{7}{|c|}{ Contribution to GDP growth ( $\%$ points) } \\
\hline 1970s (1971-80) & 1.5 & 2.2 & 1.8 & 0.4 & 3.4 & 8.4 \\
\hline 1980s (1981-90) & 0.6 & 0.9 & 1.8 & 0.2 & 2.3 & 6.2 \\
\hline 1990s (1991-2000) & 0.1 & 0.8 & 2.6 & 0.3 & 3.9 & 7.5 \\
\hline $2000 \mathrm{~s}(2001-10)$ & 0.3 & 0.1 & 1.4 & 0.1 & 3.0 & 4.9 \\
\hline Pre-GFC (2002-07) & 0.3 & 0.4 & 1.8 & 0.1 & 3.2 & 5.9 \\
\hline Post-GFC (2010-12) & 0.2 & -0.1 & 1.8 & 0.4 & 3.8 & 6.1 \\
\hline
\end{tabular}

Source: Computed from Department of Statistics Malaysia National Accounts Statistics; data rebased to 2005 constant prices. Totals may not tally due to import taxes and rounding. 
Table 6. Key indicators from the 2005 input-output table for Malaysia

\begin{tabular}{|c|c|c|c|c|c|c|c|c|c|c|}
\hline \multirow[b]{2}{*}{ Activity } & \multicolumn{5}{|c|}{ Value (RM million) } & \multicolumn{2}{|c|}{ Share of total (\%) } & \multicolumn{3}{|c|}{ Key industry ratios (\%) } \\
\hline & $\begin{array}{c}\text { Gross } \\
\text { output }\end{array}$ & Inter-mediates & $\begin{array}{l}\text { Value } \\
\text { added }\end{array}$ & Exports & Imports & $\begin{array}{c}\text { Gross } \\
\text { output }\end{array}$ & Value-added & $\begin{array}{c}\text { Value-added } \\
(\%)\end{array}$ & $\begin{array}{c}\text { Export } \\
(\%)\end{array}$ & $\begin{array}{c}\text { Import } \\
(\%)\end{array}$ \\
\hline $\begin{array}{l}\text { Food } \\
\text { agriculture }\end{array}$ & 14,167 & 5,611 & 7,795 & 1,585 & 758 & 0.9 & 1.5 & 55.0 & 11.2 & 5.3 \\
\hline $\begin{array}{l}\text { Plantation } \\
\text { crops }\end{array}$ & 28,769 & 8,458 & 18,177 & 5,196 & 2,108 & 1.8 & 3.6 & 63.2 & 18.1 & 7.3 \\
\hline Forestry & 9,227 & 1,299 & 6,251 & 2,401 & 825 & 0.6 & 1.2 & 67.7 & 26.0 & 8.9 \\
\hline Fisheries & 7,838 & 3,005 & 3,934 & 583 & 844 & 0.5 & 0.8 & 50.2 & 7.4 & 10.8 \\
\hline $\begin{array}{l}\text { Crude oil \& } \\
\text { gas }\end{array}$ & 90,651 & 14,866 & 71,472 & 46,543 & 4,241 & 5.7 & 14.0 & 78.8 & 51.3 & 4.7 \\
\hline $\begin{array}{l}\text { Mining \& } \\
\text { quarry }\end{array}$ & 4,759 & 2,580 & 1,752 & 1,540 & 410 & 0.3 & 0.3 & 36.8 & 32.4 & 8.6 \\
\hline Food products & 32,803 & 18,015 & 6,145 & 8,332 & 8,566 & 2.0 & 1.2 & 18.7 & 25.4 & 26.1 \\
\hline Oils \& fats & 54,037 & 44,070 & 6,462 & 22,165 & 3,273 & 3.4 & 1.3 & 12.0 & 41.0 & 6.1 \\
\hline $\begin{array}{l}\text { Beverages \& } \\
\text { tobacco }\end{array}$ & 8,748 & 4,517 & 1,993 & 2,932 & 2,062 & 0.5 & 0.4 & 22.8 & 33.5 & 23.6 \\
\hline Textiles & 8,845 & 4,771 & 1,735 & 3,708 & 2,305 & 0.6 & 0.3 & 19.6 & 41.9 & 26.1 \\
\hline Apparels & 6,615 & 2,614 & 2,545 & 4,063 & 1,428 & 0.4 & 0.5 & 38.5 & 61.4 & 21.6 \\
\hline $\begin{array}{l}\text { Wood } \\
\text { products }\end{array}$ & 16,120 & 9,510 & 4,699 & 9,715 & 1,867 & 1.0 & 0.9 & 29.2 & 60.3 & 11.6 \\
\hline $\begin{array}{l}\text { Paper \& } \\
\text { furniture }\end{array}$ & 25,203 & 13,322 & 7,148 & 10,477 & 4,592 & 1.6 & 1.4 & 28.4 & 41.6 & 18.2 \\
\hline $\begin{array}{l}\text { Printing \& } \\
\text { publishing }\end{array}$ & 6,878 & 3,028 & 2,418 & 999 & 1,413 & 0.4 & 0.5 & 35.2 & 14.5 & 20.5 \\
\hline Chemicals & 71,548 & 34,531 & 19,283 & 36,771 & 17,178 & 4.5 & 3.8 & 27.0 & 51.4 & 24.0 \\
\hline Petroleum & 84,815 & 58,398 & 4,753 & 20,583 & 20,745 & 5.3 & 0.9 & 5.6 & 24.3 & 24.5 \\
\hline Rubber & 21,325 & 14,192 & 3,971 & 6,330 & 2,936 & 1.3 & 0.8 & 18.6 & 29.7 & 13.8 \\
\hline Plastic & 21,602 & 9,356 & 5,392 & 6,849 & 6,753 & 1.3 & 1.1 & 25.0 & 31.7 & 31.3 \\
\hline $\begin{array}{l}\text { Non-metallic } \\
\text { min. prods }\end{array}$ & 17,673 & 9,417 & 4,615 & 4,451 & 3,535 & 1.1 & 0.9 & 26.1 & 25.2 & 20.0 \\
\hline Basic metal & 34,855 & 17,354 & 6,135 & 14,428 & 11,271 & 2.2 & 1.2 & 17.6 & 41.4 & 32.3 \\
\hline $\begin{array}{l}\text { Fabricated } \\
\text { metal }\end{array}$ & 32,412 & 16,669 & 5,018 & 7,672 & 10,599 & 2.0 & 1.0 & 15.5 & 23.7 & 32.7 \\
\hline Machinery & 19,046 & 7,986 & 4,648 & 10,198 & 6,358 & 1.2 & 0.9 & 24.4 & 53.5 & 33.4 \\
\hline $\mathrm{E} \& \mathrm{E}$ & 360,540 & 143,547 & 51,567 & 246,883 & 165,121 & 22.5 & 10.1 & 14.3 & 68.5 & 45.8 \\
\hline Transport & 51,643 & 25,757 & 4,700 & 11,846 & 14,991 & 3.2 & 0.9 & 9.1 & 22.9 & 29.0 \\
\hline $\begin{array}{l}\text { Prof \& } \\
\text { scientific eqpt }\end{array}$ & 16,497 & 6,121 & 3,717 & 10,708 & 6,636 & 1.0 & 0.7 & 22.5 & 64.9 & 40.2 \\
\hline $\begin{array}{l}\text { Other } \\
\text { manufactures }\end{array}$ & 5,181 & 1,822 & 2,156 & 2,439 & 1,192 & 0.3 & 0.4 & 41.6 & 47.1 & 23.0 \\
\hline $\begin{array}{l}\text { Electricity, gas } \\
\& \text { water }\end{array}$ & 35,149 & 18,183 & 13,865 & 2,243 & 2,940 & 2.2 & 2.7 & 39.4 & 6.4 & 8.4 \\
\hline Construction & 61,070 & 29,594 & 15,810 & 55 & 15,311 & 3.8 & 3.1 & 25.9 & 0.1 & 25.1 \\
\hline $\begin{array}{l}\text { W\&R trade, } \\
\text { hot \& rest. }\end{array}$ & 105,103 & 36,103 & 63,964 & 13,408 & 4,863 & 6.6 & 12.6 & 60.9 & 12.8 & 4.6 \\
\hline Transport & 119,451 & 69,561 & 40,585 & 23,776 & 9,005 & 7.4 & 8.0 & 34.0 & 19.9 & 7.5 \\
\hline $\begin{array}{l}\text { Finance, ins. \& } \\
\text { real est. }\end{array}$ & 140,522 & 55,185 & 75,898 & 30,332 & 9,276 & 8.8 & 14.9 & 54.0 & 21.6 & 6.6 \\
\hline $\begin{array}{l}\text { Education \& } \\
\text { health }\end{array}$ & 35,007 & 12,951 & 18,655 & 72 & 3,393 & 2.2 & 3.7 & 53.3 & 0.2 & 9.7 \\
\hline $\begin{array}{l}\text { Public } \\
\text { administration }\end{array}$ & 44,319 & 21,840 & 16,642 & 5,108 & 5,816 & 2.8 & 3.3 & 37.5 & 11.5 & 13.1 \\
\hline Other services & 11,491 & 5,349 & 5,375 & 2,151 & 277 & 0.7 & 1.1 & 46.8 & 18.7 & 2.4 \\
\hline $\begin{array}{l}\text { Gross } \\
\text { in/output }\end{array}$ & $1,603,907$ & 729,584 & 509,272 & $\mathbf{5 7 6 , 5 4 2}$ & 352,891 & 100.0 & 100.0 & 31.8 & 35.9 & 22.0 \\
\hline
\end{tabular}

Source: Computed from 2005 Input-output Table of Malaysia, Department of Statistics Malaysia. To estimate the magnitude of domestic final demand needed to absorb a $10 \%$ drop in exports, the Leontief inverse matrix $(\mathrm{I}-\mathrm{A})^{-1}$ is applied to the respective final demand aggregates to derive the gross output 
As indicated by the export ratio, many industries are heavily dependent on overseas markets with the highest being electrical and electronics $(68.5 \%)$ and professional and scientific equipment $(64.9 \%)$ with an overall average of $35.9 \%$ for the country's total gross output in 2005 .

The computation results showed that a $10 \%$ decline in exports will result in a loss of export earnings amounting to RM57.7 billion and a reduction in gross output of RM104.8 billion. To offset, this volume of gross output, domestic demand will have to be raised by an estimated $19 \%$.

\subsubsection{Impact of Changing Demand on Industries}

Although domestic final demand can be raised at the aggregate level, the sectoral impact will vary according to the composition of export and domestic demand. The differences for the 34 industry groupings are shown in Figure 11 assuming that the respective demand structure remains unchanged for export and domestic demand.

While the aggregate effects of an export decline could be offset to some extent by raising domestic demand, the above analysis indicates that industries with high exposure to foreign markets, particularly the electrical and electronics industry, will remain vulnerable (the difference for each industry group is indicated by the shaded region).

\subsection{Productivity Shifts that May Arise from DDDG}

An assessment on whether the shift to DDDG detected in the 2000s is accompanied by a decline in productivity will provide some indication of the possible affliction by Baumol's disease.

From the growth decomposition results shown in Table 4 (page 11), it is seen that the country's total factor productivity (TFP) growth had slowed from $2.0 \%$ per annum in the 1991-00 period to $1.6 \%$ in the $2001-12$ period, suggesting a slight decline in productivity associated with the period during which domestic demand was the main growth driver.

A closer look at labor productivity at the sectoral level may shed further light on the productivity trends according to their ELG or DDDG orientation. The value added for the major economic sectors in constant 2005 prices are divided by total employed to obtain value added per employee. The yearly changes in the value added per employee or labor productivity are shown in Table 7.

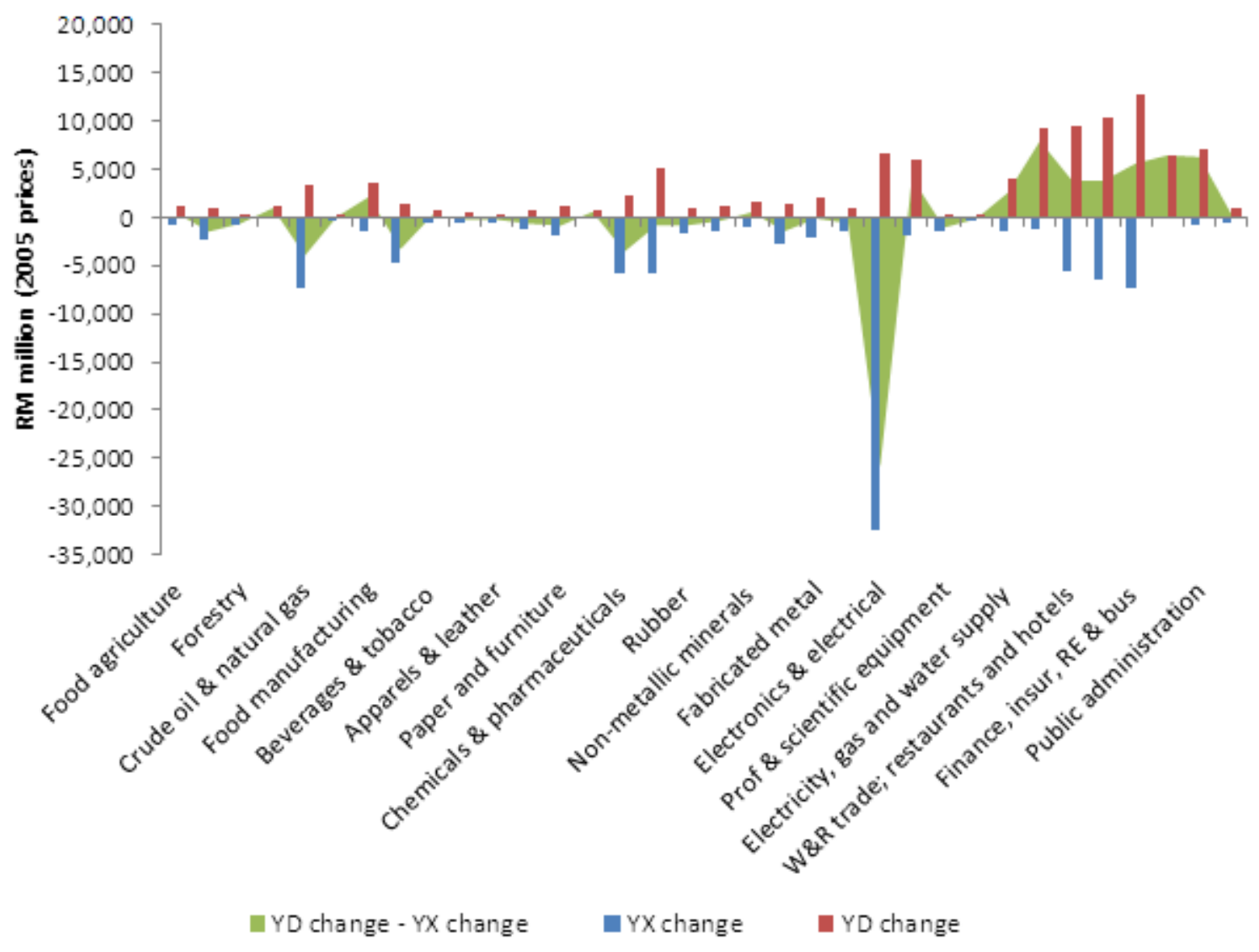

Note: $\mathrm{YD}=$ Gross output of domestic demand; $\mathrm{YX}=$ gross output of export demand

Figure 11. Sectoral impact of offsetting export demand with domestic demand 
Table 7. Labor productivity growth by major production sectors

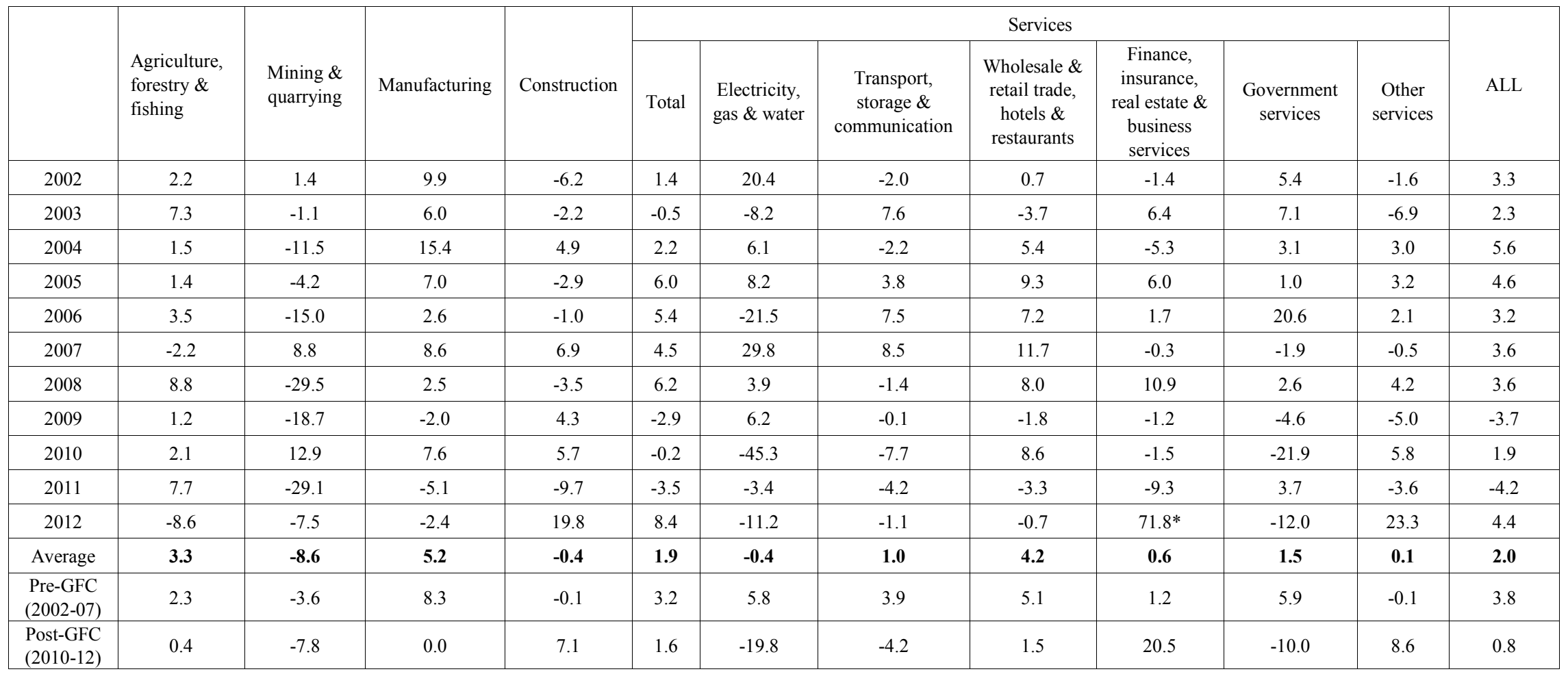

Note: * Employment was reported at 700,000 in 2012 compared to 111,700 in 2011 and 955,000 in 2010, resulting a sharp spike in value-added per employee in 2012.

Source: Computed from employment and value added data in constant 2005 prices published by Department of Statistics Malaysia 
Similar to findings for other countries, the sectors recording negative or low labor productivity growth include construction, utilities, mining and quarrying, finance, government and other services. Consistent with findings in other countries, manufacturing recorded the highest labor productivity growth averaging $5.2 \%$ for the $2002-12$ period but its flat growth during the post-GFC period (2010-12) is a concern.

For the overall economy, the moderately strong labor productivity increases averaging $3.8 \%$ per annum during the 2002-07 period and the weaker $0.8 \%$ rise for $2010-12$ is consistent with the TFP results for the two periods.

The above findings suggest that Baumol's disease may not be evident at the economy-wide level but it manifests at the sectoral level where it afflicts the largely domestic-oriented service industries. It is evident therefore that a DDDG strategy will need to consider measures to boost productivity in the largely domestic-based services sector.

\section{DDDG Thrusts and Statistical Needs}

Fast-growing economies are characterized by their ability to diversify trade, move labor from low to high productivity sectors and generate new dynamic activities characterized by higher productivity and increasing returns to scale. To be successful in sustaining growth, a DDDG strategy cannot deviate from these core principles. These together with the analyses conducted in the preceding section have helped to highlight several key findings and tentative conclusions on how a DDDG could be used to meet Malaysia's high income aspirations as well as point to further research and statistical needs.

Having reaped the benefits of ELG over the last four decades and reached upper middle income status, the shift to DDDG appears to be a natural progression in the stage of economic development in Malaysia. As noted by Temple [5], for DDDG to be effective, policy makers not only have to focus on the proximate and wider sources of growth, but also to cultivate the deep sources of growth which focus on the quality of institutions (including government effectiveness, good governance, accountability, social capital, etc.).

A schematic diagram illustrating the framework for sustaining DDDG and the accompanying statistical needs is depicted in Figure 12. It highlights the suggested strategic focus, catalysts and behavioral change for the key components and sectors considered to be important to maximize economic growth in Malaysia. The main statistical requirements are shown in the bottom-most level. The list is not meant to be exhaustive but it is intended to highlight the areas where more disaggregated as well as detailed statistics are required for more detailed analyses to be carried out. Figure 12. A DDDG framework and statistical needs

A brief review of the key DDDG dimensions and associated statistical needs are presented below.

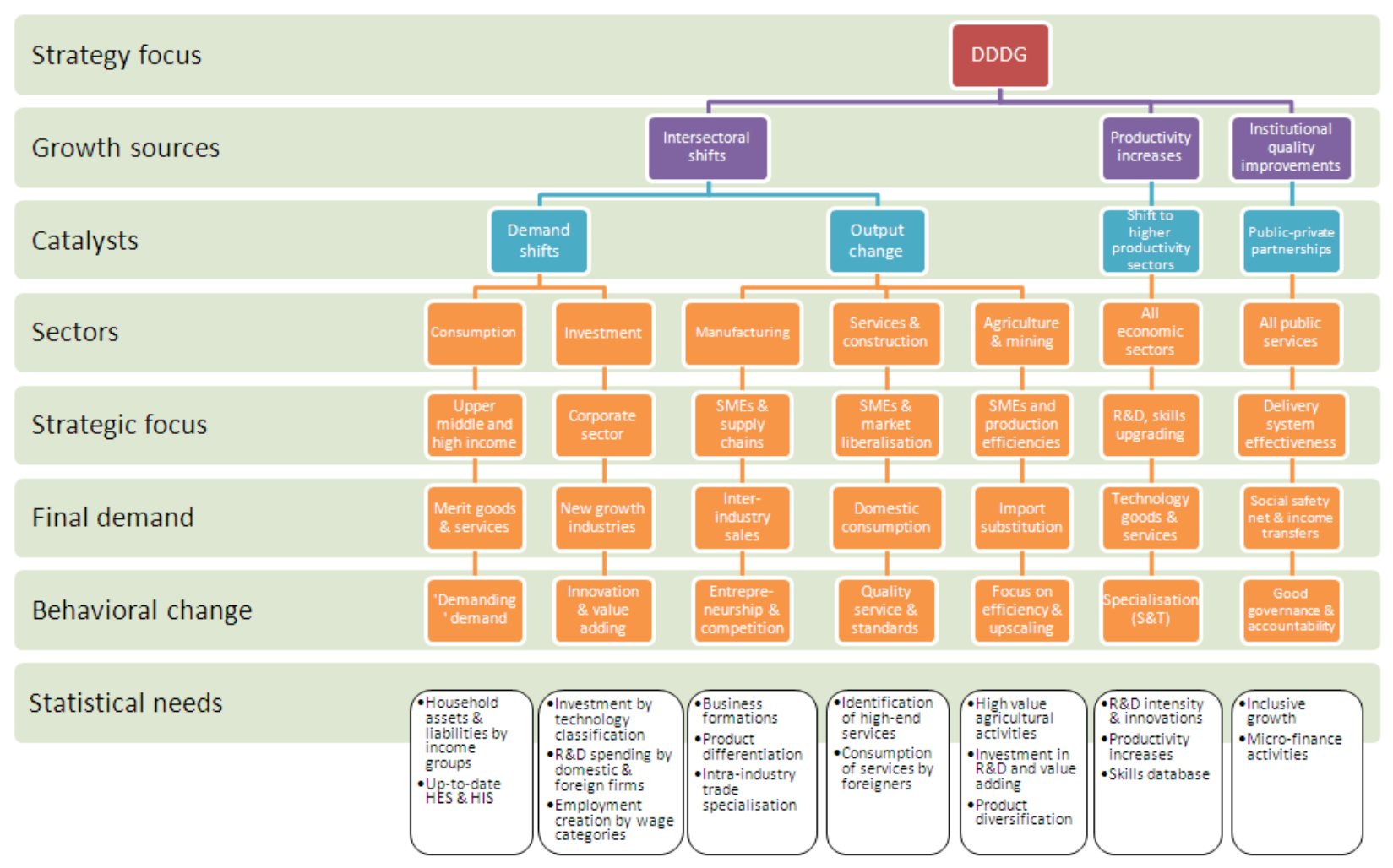




\subsection{Growth Sources and Catalysts}

\subsubsection{Inter-sectoral DDDG Thrusts and Statistical Needs}

Although the principal statistics are sufficient to perform country-level analyses on growth sources, consistent and longer series principal industry statistics are needed at a more disaggregated level to better understand the inter-sectoral shifts in output and demand, especially in tracking the movement of industries up the value chain. At the industry level, preferably at 2 and 3-digit MSIC, the availability of reliable price deflators is crucial to perform real sector analyses.

The availability of nominal and constant price industry statistics (particularly gross output and value added data) will enable such deflators to be derived for use in various growth and structural change analyses. These analyses can be further extended to include technology classification and R\&D intensity. Data on these two characteristics are crucial to better aid policy analyses and understanding on the extent to which the domestic-oriented and export-oriented industries are advancing technologically as well as developing their own innovation capabilities.

Although technology classification systems (for example, low, medium and high technology) can be adopted from those developed elsewhere (e.g. OECD), it may be appropriate to conduct a validation study before applying it locally to track the technology profile of Malaysian industries and the extent to which they upgrade and innovate in-house or through technology acquisitions. Likewise, given the importance of R\&D, its inclusion in various industrial surveys will greatly enhance the formulation and implementation of policy initiatives targeted at raising the level of R\&D in the private sector. Any boost to R\&D spending will contribute to domestic demand-led expansion as well as the creation of high skills-high wage employment.

\subsubsection{Productivity-Led DDDG Thrusts and Statistical Needs}

Given that productivity increases is the key to competitiveness and sustainable high growth, the shifts to sectors that have higher productivity (particularly manufacturing), and investment in technology, innovations, R\&D and skills upgrading that leads to higher productivity increases across all sectors are essential for DDDG to avoid the cost and price increases associated with Baumol's diseases.

Productivity analyses are often fraught with challenges especially with regards to reliable labor and capital investment statistics. The recent addition of capital stock statistics by the Department of Statistics Malaysia (DOSM) has filled a gaping hole in analyzing the country's macro-level productivity performance. Further statistical needs relate to the availability of disaggregated or sub-components such as labor categories by skill levels and types of capital investment (equipment and machineries, R\&D, technology, etc.) as these will enable more refined and useful analysis of productivity performance and understanding of its determinants at the industry level.

In line with the institutional view of 'deep' sources of growth, developing high quality institutions, enhancing government effectiveness, and focusing on social safety net and well-targeted income transfers will help to boost DDDG. The behavioral change that inculcates good governance and accountability in both the public sector and private sector is critical for DDDG to avoid the critique that import substitution and other domestic-oriented development strategies will likely fail because of institutional failures and poor governance.

\subsection{Sector Thrusts, Strategic Focus and Final Demand}

\subsubsection{Consumption-Led DDDG Thrust and Statistical Needs}

A DDDG strategy to address the 'under-consumption' phenomenon has to be holistic as well as consider inter-generation transfer issues. The suggested DDDG focus on upper middle and high income groups, given their higher contribution to excess savings, is to encourage spending on goods and services that have large multiplier effects as well as on merit goods that have positive externalities such as enhancing consumers' well-being in terms of health or skills upgrading. The availability of data and statistics that enable 'merit' goods and services to be identified and their multiplier effects or 'positive externalities' to be quantified are highly pertinent to the design and implementation of DDDG strategies.

For the low income groups, the use of direct income transfers, targeted subsidies and programs that expand their income will help to augment aggregate consumption. Increasing the efficiency and effectiveness of government spending will also boost the multiplier effects on the economy.

Ensuring prudent financing of consumption is also important as overleveraging can also lead to 'boom' and 'bust' cycles in consumer demand. Sophistication of demand or 'demanding' demand is the required behavioral change as it is one of the national competitive advantages in that it creates the pressure for industries to innovate, upgrade and meet exacting demand standards.

Besides up-to-date Household Expenditure Surveys (HES) and Household Income Survey (HIS), a DDDG strategic focus on raising consumption is the availability of data on household assets and liabilities by income groups. In some countries, surveys that began as industry-led initiatives to provide detailed household finance data for more focused marketing by financial institutions eventually became regular sectoral surveys mounted to provide useful information on the status of household finances in the country.

\subsubsection{Investment-led DDDG Thrust and Statistical Needs}

The focus on corporate investment, as spotlighted under the Economic Transformation Programme (ETP), is an obvious core DDDG driver given the country's 
under-investment phenomenon. Investment in capacity expansion, technological upgrading, R\&D, product innovation and new businesses is the key to sustaining the country's long term growth. In relation to investment data needs, a more detailed breakdown of the types of capital investment and industries by technology classification will be helpful to ascertain the ability of the industries to move up the value chain.

A diversified and broad-based economy is more resilient to external shocks. It also provides more income-generating opportunities as well as enables an optimal utilization of resources to drive DDDG. Consequently, statistics on business formations, new industries and product diversification are useful to understand the dynamics of existing and new industries as well as changes in competition dynamics.

Statistics that capture the direct and indirect investment activities of SMEs, supply chains, market liberalization, production efficiencies and competitive markets are also needed to determine the extent to which DDDG can be sustained through enhancements in economic efficiency, inclusivity, innovativeness, entrepreneurship and delivery of high quality services and standards.

\section{Conclusion and the Way Forward for DDDG}

In examining Malaysia's relatively successful ELG strategy since its adoption in the early 1970s, it is instructive to relate to the prevailing global economic environment and optimize the country's sources of growth, irrespective of the external or domestic demand orientation. The focus of the analyses on the viability and challenges of the DDDG for Malaysia therefore is not so much as to whether it can substitute ELG but rather how DDDG can be applied judiciously to complement the export sector.

A DDDG approach is feasible and sustainable for Malaysia but its limitations have to be recognized. The key findings are as follows:

- DDDG has helped to offset the weak export demand prevailing during the last decade and, importantly, during the post-GFC period.

- Although DDDG continues to predominate in the Malaysian economy today, the sizeable export capacity in a large number of industries precludes its ability to offset fully any sizeable external demand reduction. Thus, DDDG can only contribute to a partial decoupling from external demand.

- Given the different structure between domestic and export demand, there will be sectoral differences in the impact on industrial capacity, employment and income arising from the ELG-DDDG shifts.

- Malaysia's 'apparent' under-consumption and low private investment levels, in concert with a sizeable savings-investment gap, suggest that a DDDG is both feasible and desirable. Importantly, a sustainable
DDDG will need to aim at maximizing economic efficiency and utilization of resources, skills, human capital, and physical and social infrastructures.

- Despite Malaysia's under-consumption and under-investment, a DDDG strategy is also subject to the fallacy of composition; in this case, what is true at the aggregate level is not necessary true for some components. As noted, spending limitations are already evident in the government sector and the household sector, both being constrained by high debt levels.

- On the consumption side of DDDG, a higher level of spending by the middle and upper income groups will need to be elicited while the income of the low income groups will need to be boosted. The focus of the ongoing Economic Transformation Programme (ETP) on private investment, regardless of domestic or foreign sources, will be the main driver of DDDG, given the excess savings in the private sector and the capacity and productivity growth associated with gross fixed capital formation.

Although international trade has slumped since the onset of the global financial crisis in 2008/09, it is not expected to remain in a prolonged state of doldrums as the crisis-hit advanced economies gradually rebuild household and corporate balance sheets and public finances. In spite of the intensifying global economic integration as countries continue to pursue market reforms, liberalize foreign trade and investment policies and forge trade pacts bilaterally and regionally, a DDDG strategy is needed for export-oriented countries such as Malaysia to optimize the sources of growth as well as to damp fluctuations of output that is increasingly vulnerable to global demand instability.

It is reiterated that domestic demand-driven growth (DDDG) should not be viewed as a substitute for export-led growth (ELG) strategies. Rather, by harnessing the complementarities of the two paradigms, Malaysia can capture the growth opportunities arising from an upswing in external demand while mitigating the adverse effects on output and employment due to volatile export markets by strengthening the resilience of domestic demand.

Applying a holistic DDDG framework, the key strategy components and statistical needs can be grouped broadly into four thrusts:

- Inter-sectoral DDDG thrusts and statistical needs: Inter-sectoral shifts in output and demand arising from DDDG need to be closely monitored through the provision of nominal and constant price output and value added data at a disaggregated industry level (preferably 2 or 3 digit MSIC) so that structural change, productivity shifts and industry competitiveness can be analyzed. Information on technology classification and R\&D intensity are also important to monitor the desired shift up the value chain and technology ladder.

- Productivity-led DDDG thrusts and statistical needs: Productivity growth is the key to sustaining 
competitiveness and growth. Further statistical needs relate to the availability of disaggregated or sub-components such as labor categories by skill levels and types of capital investment (equipment and machineries, R\&D, technology, etc.) as these will enable more refined and useful analysis of productivity performance and understanding of its determinants at the industry level.

- Consumption-led DDDG thrusts and statistical needs: Given the constraints posed by rising indebtedness, a DDDG focus on raising consumption will require the availability of data on household assets and liabilities by income groups. The suggested DDDG focus on upper middle and high income groups, given their higher savings and ability to withstand rising inflation, is to encourage spending on goods and services that have large multiplier effects as well as on merit goods that have positive externalities such as enhancing consumers' well-being in terms of health or skills upgrading. The availability of data and statistics that enable 'merit' goods and services to be identified and their multiplier effects or 'positive externalities' to be quantified are highly pertinent to the design and implementation of DDDG strategies.

- Investment-led DDDG thrusts and statistical needs: Given that under-investment continues to prevail in the private sector, it is appropriate for DDDG to focus on promoting capacity expansion, technological upgrading, $\mathrm{R} \& \mathrm{D}$, product innovation and investment in new businesses. A more detailed breakdown of the types of capital investment and industries by technology classification will be helpful to ascertain the ability of the industries to move up the value chain. Additionally, statistics on business formations, establishment of new industries and new product diversification are useful to understand the dynamics of existing and new industries as well as changes in their competition dynamics.

\section{REFERENCES}

[1] Yeah, KL (2012). "Domestic Demand-Driven Growth", Paper presented at the National Economic Outlook Conference (NEOC) 2013-2014, organized by the Malaysian Institute of Economic Research (MIER), 4-5 December 2012, Kuala Lumpur, Malaysia.

[2] Palley, Thomas I. (2011). The Rise and Fall of Export-led Growth, Working Paper No. 675, Levy Economics Institute.

[3] Lai, YW (2004). The role of domestic demand in the economic growth of Malaysia: A cointegration analysis. International Economic Journal, Volume 18, Number 3, September 2004, pp. 337-352 (16).

[4] Nordhaus, William D. (2006). "Baumol's Diseases: A Macroeconomic Perspective", Working Paper 12218 National Bureau of Economic Research (http://www.nber.or g/papers/w12218)

[5] Temple, Jonathan. (1999). "The New Growth Evidence", Journal of Economic Literature, Vol. 37, No. 1. (Mar., 1999), pp. 112-156. 